\title{
Tribunal Regional do Trabalho
}

\section{Região \\ MANDADO DE SEGURANÇA TRT $14 \quad \mathrm{MS}-57$}

Eqüidade não se confunde com dtreito liquido e certo. Assim, não posstbilita a concessão do mandado de segurança.

Advogado dos impetrantes, JoAquiM MÁXimo de CaRvalho Júnior.

Vistos, relatados e discutidos os presentes autos de Mandado de Segurança, em que são partes, IVAN RoDrigues e outros, como impetrantes, e, como impetrado, o Tribunal Regional do Trabalho da Primeira Região. Acordam os Juízes do Tribunal Regional do Trabalho da Primeira Região, por maioria, não conhecer do mandado, vencido o Juiz FERREIRA DA Costa, na forma do Relatório e do voto que se seguem. Relatório $\left.1 .^{\circ}\right)$ - Visam os impetrantes, funcionários excercentes de cargo isolado, obter que êste Tribunal lhes assegure o direito de rece. ber vencimentos correspondentes ao Simbolo P.J. 7, de acôrdo com o disposto no art. $10^{\circ}$ da Lei n. ${ }^{\circ} 488$, de $16-5-55.2^{\circ}$ ) lnformando, disse o Exmo. Sr. Dr. Juiz Presidente dêste Tribunal o seguinte: «O mandado de segurança é impetrado contra decisão do Tribunal, cujo teor segue: - «Processo TRT $336 \mathrm{EP} / 57$. Pedido de enquadramento na Lei $\mathrm{n}^{\circ} 2.488$, de 16 de maio de 1955, que se indefere por falta de fundamento. «Vistos, relatados e discutidos êstes autos, em que são requerentes, IVAN RoDRIGUES e outros: 1. Os requerentes, Oficiais de Justiça nas Juntas de Conciliação e Julgamento do Distrito Federal recentemente criadas, pediram fôssem apostilados os de. cretos de suas nomeações nos têrmos da Lei n. ${ }^{\circ} 2.488$, de 16 de maio de 1955 , e efetuado o pagamento dos vencimentos dos requerentes de acôrdo com a referida lei, modificada pela que aumentou os vencimentos dos funcionários públicos (petição de fls. 2 a 7 ). A douta Procuradoria Regional escusou-se de opinar (fls. 10). Os oficiais das antigas
Juntas intervieram no processo como assistentes (fls. 11 a 15). 2. A Lei n. ${ }^{\circ}$ 2.488, a que se arrimam os requerentes, e como se lê de sua «ementa» «altera os valores dos símbolos referentes aos vencimentos de cargos isolados e funções gratificadas nas secretarias e serviços auxiliares dos órgãos do $\mathrm{Po-}$ der Judiciário». Ora, a «ementa» - da lei facilita a sua inteligência - já dizia o Assento $n .^{\circ} 282$, de 29 de março de 1770 . Por conseguinte, se a lei visa alterar os valores dos simbolos, dúvida não pode existir de que o sentido do seu art. $1 .^{\circ}$, segundo o qual «os simbolos... passam a ter os seguintes valores..." nã̃o é aquêle que the emprestam os requerentes. Se êstes não tinham seus vencimentos fixados por «simbolo», cujos valores pudessem sofrer «alteração», claro está que se thes não aplica a lei que atribuiu aos «simbolos» novos valores. Não colhe o argumento de que $\circ$ art. $7 .^{\circ}$ da Lei $n .^{\circ} 2.188$ (cargos e funções do Poder Executivo), que serviu de «modêlo» à Lei n. ${ }^{\circ} 2.488$, não precisava ser estendido aos órgãos do Judiciário, o que importaria uma superfetação, porque os servidores de que cogita (ocupantes de cargo de chefia) já estão incluídos na expressão mais alta «cargos isolados», do artigo $10^{\circ}$. E não colhe porque também o art. $10^{\circ}$ da Lei $n .^{\circ} 2.188$, usa, exatamente como o art. 1. da Lei n. ${ }^{\circ} 2.488$, a expressão «cargos isolados». Tal como a Lei n. ${ }^{\circ} 2.488$, a Lei n. ${ }^{\circ} 2.188$ altera os valores de simbolos (as «ementas》 de ambas são semelhantes). Por isso mesmo, tornou-se necessário dispusesse o legislador, expressamente, sôbre o enquadiramento de certas funções para as quais ainda não haviam sido estabelecidas gratificações ou reajustadas aos valores fixados na Lei n. ${ }^{\circ} 488$ e alteradas pela nova lei. Dai, os arts. $30^{\circ}$ e $70^{\circ}$ da Lei n. ${ }^{\circ}$ 2.188, artigos êstes não estendidos aos servidores do Judiciário (art. $5 .^{\circ}$ da Lei número 2.488). Mas ainda que essa extensão houvesse ocorrido, não beneficiaria os requerentes, que não se incluem em qualquer das funções referidas nos arts. $30^{\circ}$ e $7 .^{\circ}$ da Lei n. ${ }^{\circ} 2.188$ (de chefia, die assistentes, de assessôres ou secretários). Os precedentes invocados na petição de fls. 2 a 7 resultaram do cumprimento de decisão do egrégio 
Tribunal Superior que, bem ou mal, entendeu de aplicar aos servidores do Judiciário tais artigos da Lei n..$^{\circ} 2.188$, artigos que, como se disse, não aproveitam aos requerentes. Note-se, quanto aos requerentes oficiais das novas Juntas - que a $1 \mathrm{ei}$, por fôrça da qual foram nomeados posterior àquela em que fundam o pedido fixoulhes determinado padrão de vencimentos. Como aplicar-lhes, assim, lei anterior, que apenas alterou os valores de simbolos? Tanto é nenhum o fundamento do pedido que os peticionários requerem, vagamente, a apostila de seus títulos «nos têrmos da Lei $\mathrm{n}^{\circ} 2.488$ ». Falta-lhes na lei a base indispensável para um ped do claro e preciso. 3. Pelo exposto, acordam os Juizes do Tribunal Regional do Trabalho dia Primeira Região, pelo voto de desempate, indeferir o enquadramento requerido. «Rio de Janeiro, 2 de agôsto de 1957. - Amaro Barreto da Silva, Presidente. Délio Barreto de Albuquerque Maranhão, Relator. - "Ciente: NiLo BASTOS, Procurador Adjunto Substituto». Nisso se resume tôda a informação desta presidência, pois nada mais se tem a dizer. Em 27 de novembro de 1957. - Amaro Barreto". Voto - Para que se concecia o mandado de segurança, medida excepcional, é pressuposto indispensável a existência de direito liquido e certo, mas o que pretendem os impetrantes, face ao que dispõe a lei invocada, a meu ver, só lhes pode ser deferido por eqüidade, uma vez que tanto o julgado do Colendo Tribunal Superior do Trabalho, como a Lei por ôles invocados. são anteriores à lei pela qual foram nomeados. Assim, embora se possa entender ser injusta e absurda a situação, não há como reprová-la pelo caminho do mandado de segurança, de vez que a eqüidade não se confunde com o direito liquido e certo. Rio de Janeiro, 10 de fevereiro de 1958. - Délio Barreto de Albuquerque Maranhão, Juiz no exercicio da Presidência. João Batista de Almeida, Relator. - Ciente: Alvaro Lins Júnior, Procurador Adjunto Substituto.

$$
\text { D.O. de } 26-2-58 \text { - p. } 905 .
$$

